\title{
Shadow of Conventional Financial Industry on Islamic Banking: The Case against Market Competition and Concept of Risk in Islamic Financial Industry
}

\author{
Omar Javaid ${ }^{1}$
}

\begin{abstract}
The purpose of this study is to explore why Islamic financial institutions are seen following the footsteps of conventional financial system in terms of product formulations, while ignoring equity-based investments and contributing in distributive justice in the economy. The study focuses on two factors (1) how competition with conventional banks in the same market, for the same customers and investors eventually forces Islamic banks to deliver the same output like conventional banks; and (2) the concept of risk, how it is evaluated and mitigated in Islamic banks and how this concept sets a tone and direction of Islamic banks. The nature of study is conceptual and uses the "maqasid-ul-shariah" framework as a criterion to evaluate the outcome of the two stated factors. This comparison clearly highlights the incoherence between the outcomes of the stated factors with the ideals of Islamic economics. The study also suggests various policy recommendations which may bring the necessary changes in the long run or at least start a thought process among the key stakeholders. Future studies would be required to work out a more comprehensive and concrete strategy. The nature of problem explored in this study has not been explored in any study as yet. Therefore, this study contributes in highlighting two key issues, previously unexplored, hindering the movement of Islamic financial institutions toward their ideological goals.
\end{abstract}

Keywords: Islamic banking, Islamic economics, risk evaluation, role of shariah advisors, free market competition

\section{Introduction}

One of the major factors which give bank a lead in a modern free-market economy, like any other corporation, is the extent to which it is able to provide a smooth stream of returns to its depositors or/and investors at low risk. Therefore it is considered inevitable for a bank to optimize its investment strategy to make itself less risky and more profitable to the extent possible. It is generally believed that the banks use the money of the depositors, whose preference is safe keeping of their savings instead of earning huge profits, as otherwise the depositors might rather invest their money in stock market. Therefore the dynamics of competition in the market allows the bank which would offer the highest \& safest return to attract the most borrowers. The Islamic Banking being part of the same industry also complies with the same norms (Chapra \& Khan, 2000, p. 9).

All kinds of banks also compete with each other in terms of return on investment, customer base or market share, geographical penetration, profitability, financial stability, higher returns at lesser risks etc. Just to mention a few examples out of many: in a recent analysis Hasan \& Diridi (2010) compared performance of IBs with conventional banks after the credit crunch

${ }^{1}$ Omar Javaid, Senior Lecturer \& Phd Fellow at Institute of Business Management, Karachi, omar.javaid@iobm.edu.pk 
of 2007 while using the same parameters; a report by AtKearney (2012) recommends "As competition [between IB and Conventional Banks] intensify Islamic Banking will have to adopt more sophisticated, customer centric sales approach". Another example is of Ziyadat's report where he has compared the growth trends and market value etc. between Islamic and conventional banks (Al-Ziyadat, 2011) etc.

Such examples suggest that Islamic banks (like other Islamic financial institutions) intends to address the same target market with similar products, with similar marketing messages, while offering a religious differentiation to cash on the religiosity of Muslim customers. Therefore to attract the same target market Islamic banks find it more feasible to look similar, structurally, to the same audience, and subsequently delivers a socioeconomic impact on the society similar to their conventional counterparts. Having said this it shouldn't be surprising, for example, if we find Islamic banks reluctant to use "musharakah" and "mudarabah" the modes of finance considered more preferred in theory of Islamic finance (Usmani, 2008). This is so because such risk sharing equity based modes of finance are more risky since the bank is also obliged to even share the loss (in case if it happens) along with the profit with the depositor, in contrast with other modes such as "murabaha" and "ijarah" etc. which yields smooth and less risky inflow of profits (Ahmed, 2002, p. 28; Chapra \& Khan, 2000, p. 9).

To establish the same organizational design or structure, Islamic banks also need the same human resource, which also happens to have a career history of conventional banks; this history have a catalytic influence on the tendency of Islamic financial institutions to have an inclination, temperament \& mood of their conventional counterparts (Ahmed H. , 2002, p. 28). Subsequently, "Bankers in Pakistan ... holds that lending and borrowing operations cannot be performed on a risk-sharing basis because the announcement of a loss may cause a run on the bank. Therefore, they continued with the same conventional lending, investment and profit distribution operations in the name of Islamic banking and for ostensibly good reasons, they showed purely financial transactions as trade-based activities on paper only" (Khan \& Bhatti, 2008, p. 186). Furthermore nature of market forces, pressure of the investors, expectations of depositors, all determine the inclination of the contemporary movement of Islamic banking industry, with the people working in it, to behave in a not so different way. Guod (2010) succinctly sums up the entire picture:

Islamic banks have generally tried to structure themselves as closely to conventional banks (for a number of reasons). The primary reasons are that the people running the bank have backgrounds in conventional banking and therefore adapt their experience in conventional banking and want to move away from conventional-type products only incrementally. 
Table 1

Client wise Portfolio of Islamic Banking Industry in Pakistan (SBP, 2014)

\begin{tabular}{lrccc}
\hline & Dec-13 & Sep-14 & Sep-14 & Industry \\
\hline Corporate Sector & $71.80 \%$ & $74.80 \%$ & $76.90 \%$ & $67.40 \%$ \\
\hline SMEs & $5.10 \%$ & $3.80 \%$ & $3.60 \%$ & $6.30 \%$ \\
\hline Agriculture & $0.10 \%$ & $0.30 \%$ & $0.40 \%$ & $5.80 \%$ \\
\hline Consumer Finance & $11.60 \%$ & $13.00 \%$ & $11.90 \%$ & $6.20 \%$ \\
\hline Commodity Financing & $9.60 \%$ & $6.20 \%$ & $5.30 \%$ & $12.10 \%$ \\
\hline Staff Financing & $1.60 \%$ & $1.90 \%$ & $1.60 \%$ & $2.10 \%$ \\
\hline Others & $0.20 \%$ & $0.10 \%$ & $0.30 \%$ & $0.10 \%$ \\
\hline Total & $100 \%$ & $100 \%$ & $100 \%$ & $100 \%$ \\
\hline
\end{tabular}

Table 1 shows the consequences of mimicking the conventional banking industry. Here we see Islamic banks serving the elite class while ignoring the micro finance, SME and farmers in agriculture sector, they offer \& promote debt based products, and also are guilty of promoting materialistic values of consumerism in the society. The global picture of Islamic banking practices isn't any different (Khan \& Bhatti, 2008, p. 50).

The problem henceforth is that the socioeconomic outcomes of competition with the conventional financial institutions and evaluation of risks in a conventional way is not encouraging from the perspective of the ideals of Islamic economics of equitable wealth distribution, for example. This implies that substantial change, in the way Islamic banks are structured and have positioned themselves in the market, has to be brought if outcomes are to be aligned with the ideals of Islamic economic theory. This paper attempts to make a contributing in the same context by initiating a discussion on two key dimensions of banking practice and theory, namely competition with mainstream banking industry and the concept of risk assessment respectively.

\subsection{Objective, Limitations and Methodology}

This study intends to focus on the two aspects of Islamic banking industry (1) is their concept of competition with conventional banks, and (2) the concept of risk evaluation. It can be assumed in the light of citations made above that these two factors play a significant role in determining the direction and structural design of the Islamic banking industry. It is expected that questioning these two concepts, therefore, while providing an alternative compatible to the theory of Islamic economics would provide a rationale and motivation for the industry to make significant chances in the direction and the design.

It only focuses on the role of internal stakeholders of so called Islamic Banks. The political support that might be necessary nevertheless to bring around the changes proposed is beyond the scope of this paper. The alternatives described are also intend to introduce a new line of thinking however a detailed step by step strategic plan while also outlines the challenges in Pakistani context is out of the scope of the paper. In fact a separate research would be required to bring to highlight the stated changed for each country keeping in view their unique sociocultural and political realities. 
For the intended objective of the study, the methodology adopted in this paper is descriptive and comparative. The criterion of comparison will be the "maqasid-ul-shariah" framework. This framework considers the foremost objective of shariah implementation to be "hifz-uddeen" i.e. protection of deen or religiosity of society, while considers "hifz-ul-mal" i.e. protection of wealth to be least important, yet important (just to mention, in between these two objective we have "hifz-ul-nafs" or protection of self, "hif-zul-nasal" or protection of family, and "hifz-ul-aql" or protection of intellect as the other three objectives as explained Imam Ghazali for example). Therefore, the concepts and nature of competition and risk as practiced by a 'shariah compliant' banking system will be normatively analyzed in the light of "maqasid-ul-shariah" to establish 'what should be' as compare to 'what is' in $2^{\text {nd }}$ and $3^{\text {rd }}$ section respectively. The 4th section takes a more pragmatic approach and suggests what can be practically done in order to bring about the necessary change in the direction and structure of the Islamic banking industry in the light of various practical examples and best practices. The final section concludes.

\section{Concept of Risk: What it is, What it ought to be?}

Professionals in Islamic finance industry with their conventional background define, calculate, and analyze various types of 'risks' in a very conventional way. Such as 'withdrawals risk', 'credit risk', 'market risk', 'liquidity risk', 'Shariah risk', 'reputational risk' etc (Greuning \& Iqbal, 2008; Chapra \& Khan, 2000, pp. 51-6). Seref Turen summarizes the risks an Islamic Bank would face, theoretically:

.... 'converting deposit holders into suppliers of equity' and ... 'replacement of interest payments to deposit holders by profit sharing' have the tendency to lower the risk of Islamic banks but ... 'interchanging fixed loan income with the participation into profit of loan customer' will have the potential to increase the risk of Islamic bank. The overall risk of an Islamic bank will be determined by the net effect of these three factors. (Turen, 1996)

It is noted that the key aspect of financial management is risk management and "the goal of financial management is to maximize the value of a bank" (Greuning \& Iqbal, 2008, p. 64). Therefore deductively the bottom line to evaluating all these risk is either to maximize profitability or minimize any loss to the shareholders and/or depositors. It was also noted earlier that it was the same kind of perception of risks which shifted the focus of IBs toward debt based fixed income modes of finance instead of profit and loss sharing modes (Ahmed H. , 2002).

A quote from PWC (PricewaterhouseCoopers) report (on types of risks in Islamic banking) is worth mentioning which cites an example of financing of a luxury hotel, while critically noting the "complexity" in the process of deciding whether to go ahead with a project due to Shariah implications which can yield a unique set of risk for IBs:

“... an invitation [to finance construction of a hotel] which the banks' Shariah boards rejected on the grounds that the hotel contained a nightclub and bar. The banks made repeated attempts to secure permission from their boards, pointing out first that the hotel was not yet in business, then offering to finance the building above the floors 
on which the nightclub was located - to which the Shariah boards noted that the rooms of the hotel would contain minibars and alcohol. Finally, the banks argued that the sale of alcohol from minibars was such a minuscule proportion of the hotel's business that it should not play a decisive role in the judgment of the scholars - and the boards agreed. Unfortunately, the whole process took six months and the conventional banks had already gone elsewhere." (PWC, 2008, p. 7)

Assuming the above-mentioned picture is complete and true, it is clear that the risk of worldly or material loss due to complexities in the evaluation process is considered more important than the risk of failing in "akhirah" while making a financing decision. Another peculiar thing to note is that the "shariah" board has agreed to finance part of the hotel when they are assured that the construction wouldn't include the nightclub and bar etc. This may be classified as compartmentalized implementation of "shariah" as the nightclub and bar, though not being financed through Islamic modes, would indeed be a part of the hotel under construction. Nightclub and the bar being a stated feature of the hotel would be used to attract the customers, therefore the hotel as a whole, a part of which was financed through "shariah" compliant modes, would also be used to promote promiscuity and free sex culture in the society. Throughout Islamic history one hardly finds an example of hospitality industry; instead lodging service was provided free of cost to the travelers. This was so because serving the guest is of great importance in Islam, guests are considered as kindness of Allah (S.W.T), and travelers are indeed guests in a particular society. If they do not have any relative in the city then it is the responsibility of the public and the government as a whole to provide free accommodation to the travelers if they intend to earn "sawab" in "akhirah". The importance of this can be estimated from the fact that a portion of "zakat" can also be used to cater the needs of travelers even. It is although not "haraam" to charge a fee from them however keeping in view the traditions and values of Islam it is recommended to offer free service to the travelers. In the example quoted above, the financing of construction of a hotel while evaluating the source of their earning in a very narrow sense, commercialism has been given precedence over Islamic values and traditions.

Over and above, "shariah" compliant financing of the hotel has also acknowledged various features incompatible with the Islamic norms, therefore has reduced their illegitimacy to the extent they would contribute toward the hotels profit. In other words acceptance of nightclub as part of the hotel, presence of alcoholic drinks in the rooms, etc. are all weighed not in terms of the way they are condemned in Quran \& ahadith, rather by the contribution they would make in the form of numbers in the so called "halal" profits of the hotel. It may be asked whether shariah compliance financing of such projects would bring the society closer to strengthening or preserving the values of Islam ("hifz-ud-deen") or otherwise. While saving a client from one or two "haraam" acts, would it be right to contribute in creating means of indulging the public in a variety of "haraam" acts? Is it because all such factors were ignored or reduced to income generation level while deciding to finance a portion of the hotel? This example was just to present the argument; various other examples can also be quoted.

In a nutshell, from the "maqasid-ul-shariah" perspective it would not be illegitimate rather preferred to protect the interest of the depositor and investors as long as that interest is considered legitimate by "shariah", however primary objective would be to make mankind successful in hereafter (Surah Baqarah, verse 5; Surah Al Imran, verse 185), material prosperity 
would be defined a test from Allah (s.w.t) Who is also the sole provider of sustenance to mankind (Surah Al Imran, verse 14; Surah al-Anfal, verse 28; Surah al-Taghabun, verse 15).

Therefore, protection of the interest of the depositors, investors and customers would be seen in the same light, i.e. if these interests are valued as per the "maqasid-ul-shariah" framework then any negligence on the part of the financial intermediary would make the concerned primarily accountable in "akhirah" instead of primarily being accountable to the shareholders, regulatory bodies or public perception. Therefore the risk of facing the torments of hellfire may be considered the ultimate risk to be avoided by Islamic Banks so that all stakeholders remain protected on the Day of Judgment.

\subsection{Institutional Responsibility}

It may be noted that Institutions have authority and influence over the society (Rawls, 1999, p. 47; SEP, 2007), which individuals working in it may not have. Islamic Banks are also institutions therefore have an ability to influence all its stake holders and even the regulatory authorities (if all IBs take a stand against an issue for instance). Keeping this in view it can be assumed that IBs management, advisors and decision makers would be held accountable in "akhirah" for everything which falls under the institutions circle of influence.

At present this responsibility has been given to "shariah" advisors only, who advice over legality of transactional matters, whereas the remaining staff performs in a way not so differently from conventional banks as noted earlier as well. The very statement "the goal of financial management is to maximize the value of a bank" (cited above) mentioned in a book titled 'Risk Analysis in Islamic Banks' hints toward the very mindset prevalent in IBs.

The role of "shariah" board is therefore compartmentalized within Islamic banks; who should rather be in the driving seat of IFIs and act as role models for all employees to follow in terms with their commitments to Islamic ideals. It is needless to emphasize that various prohibited means of earning which are found in conventional banks are eliminated by the virtue of this board; however a lot of work is still needed to qualify the output of said institutions to be called Islamic in its true sense. Some of these areas of improvements are:

- Getting away from promoting debt and proceeding toward equity participation ("musharakah" \& "mudarabah").

- Promote Islamic values in the society while countering consumerist and capitalist values ("Hifz-ud-deen").

- Avoid inflating and debasing money supply ("Hifz-ul-mal”) (Javaid, 2015),

- Promote equitable distribution of wealth ("Hifz-ul-mal").

- Focus more on developmental matters (SME, and agricultural development for example) to achieve the above, etc.

To explain the point further let us consider an example:

There are various ahadith which discourage being indebted. Prophet Muhammad (S.A.W)

\begin{tabular}{l|llll}
\hline 34 & July-December 2014 & Volume 12 & Number 2 & JISR-MSSE
\end{tabular}


has sought refuge from debt (Sunan Nisai, p. 264, vol. 8), Maktaba Al-Matboot Al-Islamia: Halb), termed the indebted person as a prisoner (Sunan Abi Dawood, p. 119, vol. 2, AlMaktaba Al-Asriya, Syeda: Beirut), has refused to lead namaz-e-janazah (funeral prayer) of the indebted person (Sunan Nisai, p. 315, vol. 7, Maktaba Al-Matboot Al-Islamia: Halb), has informed that the soul of indebted person is suspended in his grave and his soul wouldn't enter paradise unless his debt is paid off even if he is a martyr in a holy war (Sunan Nisai, p. 314, vol. 7, Maktaba Al-Matboot Al-Islamia: Halb; Sahih Muslim 1501-2/3, Darul Ahya Al-Taras Al-Arabi: Beirut). Prophet (S.A.W) has even informed that a person who takes a debt unnecessarily or to fulfill any desire beyond his very basic need deserves the wrath of Allah S.W.T:

\footnotetext{
"The Prophet (Sal Allaahu Alaiyhi wa Sallam) said: "Whoever asks people for money when he has what is sufficient for him is only asking for more of the embers of Hell." They asked him, "O Messenger of Allaah, what is sufficient so that he does not have to ask for more?" He said: "Having enough to eat lunch and dinner." ( Mashkah Al-Masabiyh, p. 579, vol. 1, Maktaba Al-Islami: Beirut)
}

Indeed getting away from "riba" and "gharar" would save one from the wrath of Allah (S.W.T) in the "akhirah", however if the person indebted himself even if he could have survived without it (most clients of IBs would qualify, as IBs are not yet in microfinance) then obviously this would qualify him for the punishment in the hereafter. It is also possible that previously he use to avoid banking altogether however after getting attracted through promotional activity of an Islamic Bank, he decided to avail a financial service while indebting himself through "tawarruq" or "murabaha" for instance. Also he would face the wrath of Allah (s.w.t) in any case if he indebted himself for no genuine necessity, for example to upgrade his office, home or car or just to reduce his taxable income (see Modigliani-Millar's theorem). If this indebtedness is due to the promotional activity of an IB then all the IB staff which was involved in the process would also be in trouble as well from the perspective of "akhirah".

If failing on the day of judgment would be been to most significant risk within the Islamic finance industry, then the picture shown in Table 1 would have been inverse of what it is right now and IFI portfolio would be focused more on "musharakah" and "mudarabah" more than the remaining debt like modes of finance. However, this is not the obvious case.

\section{Basis of Competition, what is, what ought to be?}

Metaphorically competition is like a race where two individuals, groups, organizations, countries etc. make an effort to get ahead of their competitor while proceeding toward a destination. This destination is an objective toward which the competing parties have been striving. If the destination or the end point or criterion of the race for two individuals, organizations, groups etc. is different, then the idea of competition between the two nullifies. For example, there is no point of competition between a non-profit and for-profit organization, a mosque and a post office, a cricket team and a hockey team or a football team etc. because each of these teams or institutions strive for different ends, goals and objectives. In modern markets, a corporation's goal is to maximize his profit by fulfilling the needs and wants justified by the ontological disposition of a liberal and secular consumer. For a homo economicus ultimate need is to maximize his wealth, for which he seeks to maximize capital. 
Greed and Accumulation thus become valued and desirable. Javed Ansari, while referring to various sources of literature on modern western philosophy, notes that "for the capitalist system to be sustainable men [or women] must not recognize ... abundance. They must be obsessed by avarice and covetousness. They must want more, and more than others. Capital is the concrete form of freedom - insatiable avarice and limitless covetousness." (Ansari, 2004, Sec. 2.2). Later he notes, while commenting on financial markets which would include the banking system and other financial institutions:

"Infinite accumulation can occur only in financial markets ... [where] vices of avarice and covetousness find infinite, limitless, eternal and universal expression."

On the contrary if we look at the ethos of Islam, a completely different picture is observed. It is mentioned in the Holy Quran, Surah Takathur (Translated by Mohsin Khan):

"(1) The mutual rivalry for piling up (the good things of this world) diverts you (from the more serious things), (2) Until ye visit the graves. (3) But nay, ye soon shall know (the reality). (4) Again, ye soon shall know! (5) Nay, were ye to know with certainty of mind, (ye would beware!). (6) Ye shall certainly see Hell-Fire! (7) Again, ye shall see it with certainty of sight! (8) Then, shall ye be questioned that Day about the joy (ye indulged in!)."

The above words of the Holy Quran inarguably denounces the risk of falling into hellfire in the process of accumulating wealth in this world or getting ahead of others as this risks losing focus from real objective of getting successful in "akhirah". Various Tafaseer (commentary) of the Holy Quran such as Tafseer-e-Usmani, Tafseer Ibn-e-Kaseer, Maruf-ul-Quran, does not mention 'Mutual Rivalry' in their translation and interpretation of the first verse instead they referrers only to condemnation of unprecedented wealth accumulation and spending it not in the way as required by "shariah", which still go against the ideals of free market capitalism.

Ideally, for a financial institution to be qualified as Islamic, it must first reject the idea of competing for unprecedented wealth accumulation in competition with others, and instead focus on goals enshrined by "maqasid-ul-shariah". This makes the objectives of an Islamic financial institution (IFIs) inarguably unique in contrast with that of a conventional financial institution or a bank. If so then how IFIs can be expected to compete with conventional financial institutions? They cannot and in principle they may not.

On the contrary, it is still insisted by industry experts that Islamic banks should compete with conventional banks in the market, like Chapra, et al (2000) has repeatedly emphasized on making IBs competitive against conventional banks, while remaining strictly "shariah" compliant. The intention maybe to save as many people from "riba" and other prohibited elements, while adopting the overall theme of the banking out of compulsion as no practical option is available which would ensure a speedy conversion of masses, away from utterly "haraam" elements. The question however is, has anyone tried for an alternative or the scholars in particular, have they been able to imagine something different, if no then it would be surprising as a lot can be at least imagined in the light of examples from the past and even present times which would be discussed in the sections below. 


\subsection{Changing Objectives of Islamic Banks}

Mufti Taqi Usmani (d.b), who has been quoted already in this document, condemns the consequences of the competition and race going on in between Islamic and conventional banks to create alternatives for each and every conventional product (Usmani M. M., 2008). At this point it is imperative that the objectives of an IFI are clearly chalked out. Once these objectives are ascertained then it would be determined whether there is a need to compete with anyone in the market or not, or how the financial requirements of public is fulfilled while keeping the objectives in focus. If the demand of the public becomes incompatible with Islamic ethos, then instead of bowing down to those demands, IFI would have to step away while insisting the public to bring their demands within the boundaries of the Islamic ethos.

Like the objectives of conventional banking institutions are in sync with the objectives of free market capitalism, similarly objectives of IFIs would be synced with the objectives of Islamic socio-economic and political system; these objectives may be:

- Support and promote any activity, transaction or a project, which would bring the stakeholders closer to the ideals Islam, while avoiding any activity, project and transaction which would take the stakeholders away from Islam in short or the long run.

- Protect economic wellbeing of each of the stakeholder and public in general, strive to promote distributive economic justice, equitable distribution of wealth and avoid any activity which would cause economic injustice to public in general.

- Protect the overall socio-economic and political atmosphere, and avoid any activity which would take the society away from the ideals of Islam, in the short and long term.

- Constantly strive to fill the gaps between 'what is' and 'what ought to be', and support all other IFIs to achieve the same ends, instead of competing with them.

- Expand without compromising any of the above objectives.

Measures like market share, profitability, geographical reach etc. Remain significant from an operational perspective. In other words these would become a means to achieve the "maqasid" stated above. For example measure of market share would mean how much public is now saved from becoming a part of conventional financial sector, or profitability would be a measure to know how much possibility to expand for an IB exists so that it can save more and more people from the indulging in "haraam" trading and financing activities.

It is important to emphasize that the message of Surah Takathur even negates any motivation among Islamic banks to compete with each others for worldly gains. If so then it would be better that they join hands and form a cartel instead and support each other to promote Islamic values and incrementally move toward ideals of Islamic economics. 


\section{What can be done?}

The context of the discussion has been normative so far. Now it may be asked how the above would be achieved keeping in view the prevailing trends of the industry. An overnight change or a change in a short span of time is an unrealistic proposition. It took almost four centuries for enlightenment movement to change the religious outlook of the world to secular (Brains, 2000); it took around 150 years for East India Company to change the socio-economic and political landscape of the subcontinent (Marshall, 2011). Islamic socio-economic model would also take many decades if not centuries; however such a change is only possible with a clear vision, direction, purpose and an uncompromising resolve on the fundamental principles and ideals. Such a change also needs to be backed by appropriate political support, or at least void of any resistance from regulatory level.

Changing the basis of competition is about changing the very mindset prevalent in the industry as mentioned above. Changing the perception of risk would also require a change in the objectives and goals of the key stakeholders of the industry. This doesn't mean that at a micro level the basic functionality of a financial institution would be changed, facilities like safe keeping of deposits, payment of large sums through banks cheques, financing of commercial and public projects through profit sharing etc., would remain available, however the reasons for which all this would be done wouldn't be determined by the ideology of free market capitalism, rather by ethos of Islamic socio-economic model. This implies that IFIs would focus more on providing microfinance to the poor and farmers in the agricultural industry, doing "musharakah" or "mudarabah" with SME sector etc.

Take Akhuwat (www.akhuwat.org.pk) as an example which provides completely interest free microfinance to the poor, and yet it is sustainable with a mindboggling recovery rate of $99.8 \%$ over a whopping Rs. 7.7 billion of disbursement. Its graduated borrowers have now voluntarily become donors to help Akhuwat with its operational expenses (see website for detailed). Now Akhuwat isn't a microfinance bank therefore it doesn't really have to compete with the banks who capitalizes on the needs of the poor with interest based microfinance products under the pressures of investors. It isn't supervised by State Bank of Pakistan also therefore doesn't have to comply with banking regulations as well, nor have to employ staff from banking industry to run its operations. The example of Akhuwat is a radical one and such a huge shit for IFIs wouldn't be easy, however it nevertheless a good case to prove that by changing the rules of the game the desired objectives can be achieved much more effectively and efficiently.

\section{Changing the Brand Name}

Learning from the example of Akhuwat above, a simply strategy would be that Islamic banks rebrand themselves as something other than a bank, changing the very title would make any competition with the conventional banking industry out of context. A bank competes with a bank, a Formula-1 car compete with another Formula-1 car but not with an earth moving excavator. For example Islamic Vaults, Islamic Trading House, Islamic Industrial Development Institute, Islamic Money Managers or some Arabic word(s) or an acronym of a two or more words etc. This may not be a problem if all Islamic bank move like a cartel and persuade their regulating authority to let them change the name (of the game), and subsequently changing the rules under which they operate. If the term "bank" cannot be removed then at

\begin{tabular}{l|llll}
\hline 38 & July-December 2014 & Volume 12 & Number 2 & JISR-MSSE
\end{tabular}


least "Islamic" should be removed, as the term "Islamic Bank" is simply an oxymoron, "Interest free bank.".

Public acceptance of the new brand name would be a challenge however not an impossible task. State of the art perception management techniques can be utilized to make the new concept acceptable. Again this would not be an overnight or a sudden shift, but gradual and slow education of the public is very much possible. The ultimate example is the spread of Islam in the world, which occurred against all odds, which the help of uncompromisable resolve of sahab-e-kiram (r.a.a) over the goal and vision set by Allah's Messenger (s.a.w), especially during the Meccan period, which transformed the hearts and minds of the public, and in short span of time the entire landscape of the Arabian peninsula was transformed. This example was for inspiration, for practical purposes the decision makers in IBs may study how the conventional banks gained confidence of public over many centuries, despite many colossal failures. For example Carl Wennerlind has cited various measures which the founders of Bank of England took to gain the confidence of public, in this context he deserves to be quoted at some length:

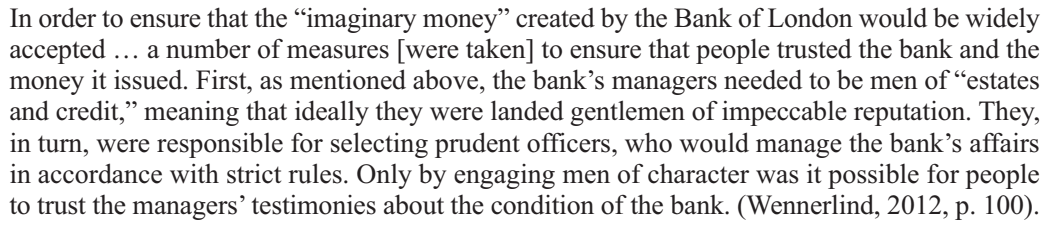

To some extent, this is already true for Islamic Banks thanks to reputation of shariah scholars who works with the banks. However once the transformation is initiated the process would be slow and gradual. In the beginning Islamic financial institutions didn't have much bargaining power and resources for this purpose, however today their presence is hard to ignore. Also they can arrange reasonable amounts of funds to educate the masses about their rebranding as well through various marketing and educational programs. In today's world of marketing and perception management this is not impossible, only if there is sufficient realization and vision among the kingpins of IFIs to detach themselves from the bandwagon of conventional financial industry and change the rules of the game so as to make the institution a means to pursue the sociocultural and economic ideals of Islam.

\subsection{Changing the Role of Shariah Advisors}

Changing the exterior would be meaningless with an analogous change of the interior, the role of shariah advisors has to be elevated from mere approvers to role models for everyone to follow, so that may influence the hearts and minds of the concerned stuff who would consider the risk of failure of "akhirah" to be supreme over other risks. This would require a special kind of insight and a holistic perspective along with an appropriate mindset at the level where key decisions about the direction of the Islamic banks are made.

Shariah Advisors may also have to take the position of 'shariah supervisors', so that they may look over all the affairs and direction in which the organization has to move, at a strategic level. It has been noted by Sophie McBain that already shariah advisors enjoy powers in Islamic Financial Industry globally where their opinion can even go against the will of CEO 
of the organization, therefore influencing the overall movement of the organization. While quoting various sources McBain explains:

\footnotetext{
Although not accountable to shareholders, the decisions of the shariah board can overrule those of the executive committee and have a decisive impact on an organization's strategy. 'Shariah scholars are still perceived by many market participants ... to be more influential than the CEO ... You can have a situation where the shariah scholar can take a decision which is entirely negative to the development of the organization, and where management can't do anything about it." (McBain, 2012)
}

Perhaps for the same reason they are offered exuberant remunerative packages, McBain while citing various sources further notes:

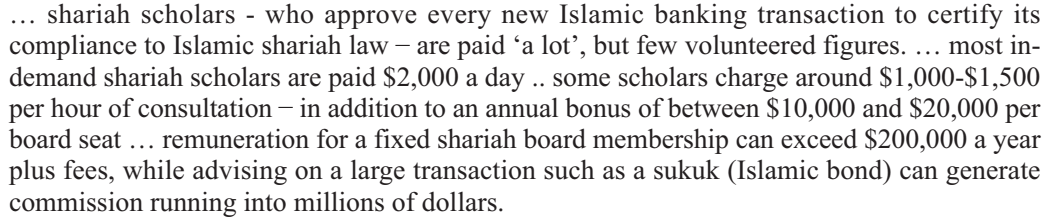
compliance to Islamic shariah law - are paid 'a lot', but few volunteered figures. ... most indemand shariah scholars are paid $\$ 2,000$ a day .. some scholars charge around $\$ 1,000-\$ 1,500$ per hour of consultation - in addition to an annual bonus of between $\$ 10,000$ and $\$ 20,000$ per board seat ... remuneration for a fixed shariah board membership can exceed $\$ 200,000$ a year plus fees, while advising on a large transaction such as a sukuk (Islamic bond) can generate commission running into millions of dollars.

This might be a problem as this makes one doubt the interest and intentions of shariah advisors. It would not be wise to categorize all advisors under the same umbrella, as there must be many who are God fearing, have clear intentions, and uncompromising attitude toward their duty. This is also acknowledged by industry specialists who quote them as "people of such a level of integrity and honesty" (Wright C. , 2006) that it seems unjustified to have any doubts about them in general.

However too much optimism in this regards would also be unwise. It wouldn't be improbable to assume that such exuberant packages might shift the interest of some advisors, as also feared by McBain (2012). It is improbable that shariah scholars would begin to legitimize what is prohibited by Islam; though a trend to sell their services to financial institutions at exuberantly high rates might shift their focus toward allowing Islamic financial industry to mimic the conventional one at least in terms of ethos. According to a BBC article, this has already been observed.

Chris Wright quoted Mufti Taqi Usmani (d.b) who while arguing against the development of shariah complaints alternates of Hedge Funds said: "many things that are not fully compliant with the basic philosophy of Islamic economics, we do not need to bring about alternatives for" (Wright, 2006). The trend of the Islamic financial industry is however contrary to the wish of Mufti Taqi Usmani (d.b). The immense power of shariah advisors to influence the dynamics of the industry is also widely acknowledged. However keeping in view of the increasing tilt toward commercialization of sole religious hinge of the industry, namely shariah scholars, how the remaining stakeholders would be expected to shift their direction away from satisfying the desires of capitalistic market?

The change, therefore, may begin from shariah advisors, i.e., instead of commercializing on their fatwa issuing capacity, they may resume toward the true spirit of this service that is of bringing the public closer to Allah (S.W.T) while considering it as "ibadah" and doing it free of charge!

\begin{tabular}{l|llll}
\hline 40 & July-December 2014 & Volume 12 & Number 2 & JISR-MSSE
\end{tabular}


One way to move forward would be to remove shariah advisors from the pay role of the banks and finance their remuneration through a separate endowment fund operated by some independent body. All "darulifta" (an institution which issues a religious decree or "fatwa") in the "madaris" operate without any fees charged from the questioner (this can be verified by visiting any madresa and darulifta in Pakistan, at least). Issuing a fatwa is a religious obligation, an "ibadat", with rewards due in hereafter.

Charging a fee from a questioner (client) seeking a fatwa is considered highly reprehensible within the boundary of this institution. If an advisor qualifies as a "mufti" (Islamic Jurist) then it is very much possible that he also serves in darulifta, hence he also would not be charging a fee there. It is a critical question as to why the same scholars working in a financial institution, where their role is also to issue fatwa or decree on various matters, takes a salary from their 'client', in such a high proportions as stated above?

"Muftian" (plural of Mufti) serving at "darulifta" do receive a salary, but not from the clients who come to seek a fatwa from them. This institution of "darulifta" is rather financed by the public, particularly the business community, for the sake of bounties in "akhirah". It is very much possible that the same financier is requested to create an extra fund to provide remunerations for the extra responsibility of shariah scholars to supervise the financial institutions where they work. This may substantially reduce the risk of any compromise in terms of overall tilting of the institution of satisfying a capitalistic ends of the society.

Furthermore at regulatory level like that of central bank, the role and responsibility of shariah scholars may be redefined in this perspective such that they are all held responsible to assess all the risks of failing in "akhirah" and keep the banks and all the stake holders away from such an eternally devastating failure. At present the key responsibility of shariah advisor as per SBP rules, for example, is to supervise the compliance of the financial products of the respective institution only (SBP, 2008c), he may offer guidance on other issues like that of marketing, HR management etc. in case the top management or BoD ask him so (ibid, p. 18).

This role needs to be more strategic in nature, i.e. while deciding the overall direction of the organization, an approval from shariah advisors, who isn't at the payroll of the bank or financial institution, might be taken. One way to do this is to make them a BoD member having a veto power over the decision of the entire board. This is only possible if the initiative is taken at a regulatory level.

Apparently it might seem that the profitability of the bank would become more and more restricted as such measures would induce an environment of religious conservatism. Voices of some high profile experts in the Islamic Financial Industry suggests that the "regulation should not be so strict and cumbersome that it hurts the profitability and development of Islamic banks and makes them uncompetitive in relation to conventional banks." (Chapra \& Khan, 2000, pp. 24-5). Such an argument is valid from a worldly perspective, however from the standpoint of metaphysical premise of Islamic belief system and "maqasid-ulshariah" competing on materialistic grounds is highly reprehensible (Surah Takathur), furthermore the "rizq" is also determined by Allah (s.w.t) therefore its concern may not supersede the concern of fulfilling ones religious duties and succeeding in "akhriah". 
Another major challenge would be an acute shortage of quality shariah advisors. McBain has noted, while quoting a secondary source (Funds@Work) that "the top ten scholars in the world make up 40 per cent of all board memberships, sharing 450 board positions between them" (McBain, 2012). This would be a major bottleneck in the way forward. A way would be the introduction of fresh blood with the appropriate mindset and a holistic perspective to see the wider implication of the actions of a financial institution. Educational institutions, "madaris" or "darululoom" of the Muslim world would have to play their role, and take urgent measures to overcome the prevailing shortage.

A part from this all educational institutions which are offering courses or programs on Islamic Finance may make it compulsory to induce realization about the greatest risks involved in the industry, i.e. the risk of failure in "akhirah", and that the real success is the success in the hereafter which is possible by following the footsteps of Prophet Muhammad (S.A.W) and his companions (r.a.a). This is how key objective of "hifz-ud-deen" in the "maqasid-ulshariah" framework will be fulfilled. Additionally they may also be taught to assume the responsibility to formally and informally strive to save all the internal and external stakeholders, to the extent possible, from this ultimate risk and success. The HR training department of the bank and financial institution may also make it a top priority to conduct regular trainings in the organization in this context, and create an environment conducive of fostering such a God fearing and religious mindset. The pivotal element in this regards is the role modeling of the top management, board members and most importantly the shariah scholars cum advisors that how they become a source of inspiration for their subordinates and colleagues.

\section{Conclusion}

Among academics Islamic financial institutions are losing their legitimacy as they have not been able to participate in redistribution and circulation of wealth among all corners of the society while helping the poor and small \& medium size enterprises. Furthermore there also isn't any significant movement in the direction of promoting increasing the share of investments through "musharakah" and "mudarabah" modes of finance which are considered more just as compare to other modes like "murabaha, ijarah, salam, istisna, tawarruk" etc. The main excuse given by the Islamic financial industry is that such a transformation is too risky to undertake while they compete with the conventional financial industry in terms of profitability and market share.

In this paper, it is argued that Islamic financial industry cannot differentiate itself unless it stop competing with their conventional counter parts by redefining its objectives and rebranding itself while also rethinking its concept of risk of failure in the light of metaphysical premise of Islamic belief system or "maqasid-ul-shariah". This is crucial as otherwise the shadow of conventional financial market and the pressure of various stakeholders to perform on the same foot prints of interest based system would not allow them to fulfill the objective of Islamic sociocultural and economic system. In this context the role of shariah advisors is seen as the most crucial as they have the moral authority to drive the necessary change in the interior and exterior of the industry. It is argued that shariah advisors must act as role models and as supervisors having the ultimate veto power. It depends upon the collective will of all concerned stakeholders to influence this transformation, particularly SBP, irrespective of how slow and gradual it may be. Islamic financial institutions therefore must take the necessary transformation by ending the difference in claims, promises and their market

\begin{tabular}{l|llll}
\hline 42 & July-December 2014 & Volume 12 & Number 2 & JISR-MSSE
\end{tabular}


practices as otherwise they would risk losing their moral legitimacy in the eyes of the public and using Islam only as an excuse to earn profits from a religiously conscious market segment of the society.

\section{References}

Ahmed, H. (2002). A Microeconomic Model of an Islamic Bank: Research Paper no. 59. Jeddah: Islamic Development Bank: Islamic Research and Training Institute.

Brains, P. (2000, May 18). The Enlightenment. Retrieved June 12, 2012. Retrieved from http://public.wsu.edu/ brians/hum_303/enlightenment.html

Chapra, M. U., \& Khan, T. (2000). Regulation and Supervision of Islamic Banks. Jeddah: Islamic Research \& Training Institute: Islamic Development Bank.

Goud, B. (2010). IMF working paper on Islamic banks in the financial crisis. Retrieved from http:/www.thereviewme.com/2010/11/imf-working-paper-on-islamic-banks-in-thefinancial-crisis-2/

Greuning, H. V., \& Iqbal, Z. (2008). Risk Analysis for Islamic Banks. World Bank Publications.

Javaid, O. (2015). Methodology of Institutional Analysis and its Implication on Expectations from the Contemporary Framework of Islamic Banks. Humanomics, 31(2).

Khan, M. M., \& Bhatti, M. I. (2008). The Development in Islamic Banking: The Case of Pakistan. New York: Palgrave Macmillan.

Marshall, P. (2011, February 17). The British Presence in India in the 18th Century. Retrieved June 12, 2012, from BBC: History:

http://www.bbc.co.uk/history/british/empire_seapower/east_india_01.shtml

McBain, S. (2012, April). Islamic Finance's 'Scholar Problem': Why Are Shariah Scholars Paid So Much? Retrieved from http://www.spearswms.com/asset management/32000/islamic-finances-scholar-problem-why-are-shariah-scholars-paidso-much.thtml

PWC. (2008). Growning Pains: Managing Islamic Banking Risks. UK: Pricewaterhousecoopers.

Rawls, J. (1999). A Theory of Justice. The Belknap Press of Harvard University Press.

SBP. (2008c). Islamic Banking Sector Review 2003 to 2007. Karachi: SBP.

SBP. (2014). Islamic Banking Bulletin. Karachi: State Bank of Pakistan. 
SEP. (2007, January 4). Social Institutions. Retrieved July 6, 2012, from Standford Encyclopedia of Philosophy: http://plato.stanford.edu/entries/social-institutions/

Turen, S. (1996). Performance and Risk Analysis of the Islamic Banks: The Case of Bahrain Islamic Bank. J.KAU: Islamic Economy, 8, 3-14.

Usmani, M. M. (2008). Looking for the New Steps in Islamic Finance. Retrieved from http://www.muftitaqiusmani.com/images/stories/downloads/pdf/islamic\%20finance $\% 20$ $\% 20$ new $\% 20$ steps.pdf

Wennerlind, C. (2011, March 14). Casualties of Credit: The English Financial Revolution 1620 - 1720. Massachusetts: Harvard University Press.

Wright, C. (2006, September). The Shariah scholar cartel: Asiamoney, September 2006. Retrieved from http://www.chriswrightmedia.com/asiamoney-sep06-shariahscholars/

$44 \quad$ July-December 2014

Volume 12

Number 2

JISR-MSSE 